\title{
Experimental bacteriophage-mediated virulence in strains of Vibrio harveyi
}

\author{
James Munro, Jane Oakey, Erin Bromage, Leigh Owens*
}

Department of Microbiology and Immunology, James Cook University, Townsville, Queensland 4811, Australia

\begin{abstract}
Vibriosis is a major disease problem in prawn aquaculture. Until now there has been no clear explanation why some strains of Vibrio are pathogenic, while others are not. This study demonstrated that the presence of the bacteriophage $V$. harveyi myovirus like (VHML) may confer virulence to $V$. harveyi Strain 642 . This was demonstrated by infecting naïve avirulent $V$. harveyi Strains 12, 20, 45 and 645 with the bacteriophage and converting them into virulent strains. The previously naïve strains of Vibrio infected with Bacteriophage VHML from V. harveyi Strain 642 demonstrated upregulation of haemolysin, up-regulation of protein excretion, additional proteins which were recognised as toxic proteins from Strain 642 by monoclonal antibodies specific to the exotoxin sub-units, and a significant increase in mortality of larval Penaeus monodon. It was concluded that Bacteriophage VHML conferred virulence to $V$. harveyi Strains 12, 20, 45 and 645 and that Bacteriophage VHML either fully or partly confers virulence in $V$. harveyi Strain 642.
\end{abstract}

KEY WORDS: Vibriosis · Vibrio harveyi · Bacteriophage · Haemolysin · Protein synthesis · Monoclonal antibodies · Penaeus monodon

\section{INTRODUCTION}

Luminous vibrios have been shown to cause serious mortalities in larval prawn systems worldwide (LavillaPitogo et al. 1990). Vibrio harveyi was identified as the predominant microorganism that caused significant mortalities associated with luminescence in larval cultures of Penaeus monodon in the Philippines (Baticados et al. 1990). Outbreaks of disease due to $V$. harveyi have also been observed in Indonesia (Sunaranto et al. 1986), Thailand (Jiravanichpaisal et al. 1994), India (Karunasagar et al. 1994), Australia (Pizzutto \& Hirst 1995) and Taiwan (Liu et al. 1996). Some strains of $V$. harveyi have caused $100 \%$ mortality in P. monodon larvae at challenge doses of $10^{2}$ colony forming units (CFU) $\mathrm{ml}^{-1}$ (Lavilla-Pitogo et al. 1990). However, the majority of strains of $V$. harveyi that have been isolated from both diseased prawns and from environmental sources do not cause mortality in P. monodon larvae at challenge doses of $10^{6} \mathrm{CFU} \mathrm{ml}^{-1}$ (Pizzutto \& Hirst 1995). Currently there is no clear explanation for the large variation in pathogenicity among strains of $V$. harveyi.

*Corresponding author. Email: leigh.owens@jcu.edu.au
Pizzutto (1992) reported that virulent strains of Vibrio harveyi could not be separated from avirulent strains on a phylogenetic basis. Subsequently, Pizzutto \& Hirst (1995) suggested that virulent isolates within $V$. harveyi are rare and that virulence may be explained by a genetic transfer of virulent factors. In 1999, Ruangpan et al. observed a bacteriophage as well as bacterial cells in Penaeus monodon tissues infected with $V$. harveyi. They reported that the phage may either promote the production of an existing toxin or somehow induce the production of a new one.

The luminous Vibrio harveyi Strain 642 has been shown by Muir (1990) to be to be virulent to Penaeus monodon. Harris \& Owens (1999) demonstrated that this strain produced a proteinaceous exotoxin capable of causing mortality in mice and $P$. monodon at 3.1 and $2.2 \mu \mathrm{g} \mathrm{g}^{-1}$ respectively. Recently, Oakey \& Owens (2000) reported a prophage in V. harveyi Strain 642. The bacteriophage was named $V$. harveyi myovirus like (VHML). This bacteriophage was shown to be able to infect a narrow host range with a preference for certain strains of $V$. harveyi. 
Previously, the infection of a specific bacteriophage into a bacterium has been shown to initiate virulence in that bacterium. This has been reported for such bacteria as Corynebacterium diphtheriae, Group A streptococci, staphylococci, Pseudomonas aeruginosa, Escherichia coli and Vibrio cholerae (Rajadhyaksha \& Rao 1965, Takeda \& Murphy 1979, Johnson et al. 1980, Hayashi et al. 1990, Waldor \& Mekalanos 1996).

The current project was designed to investigate if the infection of Bacteriophage VHML was responsible for virulence in Vibrio harveyi Strain 642. This was demonstrated by infecting previously naïve, avirulent strains of $V$. harveyi with VHML to determine whether virulence was conferred.

\section{MATERIALS AND METHODS}

Source of bacterial strains. All isolates were from the Microbiology and Immunology culture collection at James Cook University, Townsville, Australia. Vibrio harveyi Strain 642 had previously been shown to contain Bacteriophage VHML, while Strains 12, 20, 45 and 645 had previously been shown to contain no bacteriophage by Oakey \& Owens (2000). The 5 strains were initially supplied by the Sir George Fisher Centre for Tropical Marine Studies, James Cook University, with Strains 642 and 645 belonging to the Australian collection of marine micro-organisms.

Bacteriophage extraction and infection of bacteria. The methods for the extraction of the bacteriophage from Vibrio harveyi Strain 642 and the infection of the bacteriophage into the naïve hosts were as described by Oakey \& Owens (2000).

Vibrio harveyi Strain 642 was cultured in broth containing $5 \mathrm{~g} \mathrm{l}^{-1}$ peptone, $1 \mathrm{~g} \mathrm{l}^{-1}$ yeast extract and $33 \mathrm{~g} \mathrm{l}^{-1}$ synthetic sea salt, PYSS (Aquasonic) and incubated for $12 \mathrm{~h}$ on an orbital shaker at $28^{\circ} \mathrm{C}$. The culture was induced into the lytic cycle by the addition of $50 \mathrm{ng} \mathrm{ml}^{-1}$ mitomycin C (Sigma-Aldrich) and further incubated for 10 to $12 \mathrm{~h}$ on an orbital shaker at $28^{\circ} \mathrm{C}$. Cells were pelleted by centrifugation at $5000 \times g$ for $10 \mathrm{~min}$. The supernatant was harvested and filtered using a Millipore filter system through a $0.45 \mu \mathrm{m}$ disposable Millipore filter. The bacteriophage was pelleted by ultra-centrifuging the cell free supernatant at $200000 \times g$ for $4 \mathrm{~h}$. The pelleted bacteriophage was resuspended in $0.5 \mathrm{ml}$ of sterile SM buffer (Maniatus et al. 1982), and stored at $4^{\circ} \mathrm{C}$.

The 4 naïve Vibrio harveyi strains were cultured in $100 \mathrm{ml}$ aliquots of PYSS and incubated as stated previously until $\mathrm{OD}_{600}$ was approximately 0.2 . A volume of $100 \mu$ l concentrated bacteriophage extract from $V$. harveyi Strain 642 was added to the aliquots. All flasks were returned to incubation for $2 \mathrm{~h}$ to allow infection to occur. These cultures were then stored in $10 \%$ glycerol at $-20^{\circ} \mathrm{C}$ for working stock and $-80^{\circ} \mathrm{C}$ for long-term storage. All cultures with added bacteriophage and 1 without bacteriophage (control) were induced with $50 \mathrm{ng} \mathrm{ml}^{-1}$ mitomycin C and further incubated. Optical density readings were then taken periodically through the experiment to a maximum of $30 \mathrm{~h}$ post-induction. A decrease in the $\mathrm{OD}_{600}$ which was not evident in either the control or the induced control was taken as a presumptive infection with the 642 bacteriophage extract. The control and induced control were cultures of the 4 naïve $V$. harveyi which did not receive the 642 bacteriophage extract.

Preparation of cell-free supernatant. Cell-free supernatant (CFS) was prepared using a method modified from Harris \& Owens (1999). Vibrio harveyi, with and without the bacteriophage, were cultured in sterile PYSS to a density corresponding to an absorbance of 1.0 to 1.2 at $600 \mathrm{~nm}$. This corresponded to a cell density of approximately $10^{9} \mathrm{CFU} \mathrm{ml}^{-1}$. At this cell density, the concentration of toxin is at its maximum (Harris 1998). Cells were pelleted by centrifugation at $12200 \times g$ for $20 \mathrm{~min}$. The supernatant was harvested and filtered through a $0.22 \mu \mathrm{m}$ disposable syringe filter (Sartorius). A 50 to 300 times concentration of the supernatant was achieved by filtration through a $75 \mathrm{~mm}$ YM100 (100 kDa) Diaflo ultrafiltration membrane (Australasian Medical and Scientific) in an Amicon (Millipore) Model 8200 ultrafiltration stir-cell at $4^{\circ} \mathrm{C}$, under pressure of nitrogen gas applied at 100 psi.

Analysis of CFS protein profiles by SDS-PAGE. Estimation of total protein in solution was performed by the Pierce bicinchoninic acid assay (Progen Industries). One-dimensional polyacrylamide gels of $7.5 \mathrm{~cm}$ length, using $0.75 \mathrm{~mm}$ spacers, with a $12 \%$ separating gel were prepared and run by the method of Pizzutto (1992), being a modification of the method of Laemmli (1970). The CFS from each strain of Vibrio harveyi with and without the bacteriophage was diluted with PBS to a uniform protein concentration. This was then diluted with SDS-reducing buffer at a ratio of 1:1. Samples were boiled for $5 \mathrm{~min}$ and used immediately in SDS-PAGE. Electrophoresis was performed at 125 $\mathrm{V}$ until the tracking dye left the bottom of the gel. Protein bands were visualised by staining with silver stain.

Determination of differences in haemolysin production of strains infected with phage from Vibrio harveyi Strain 642. Dual layer agar plates were prepared by making a thin PYSS agar $(1.5 \%$ agar) layer and overlaying this with PYSS agar $(1.5 \%$ agar $)$ containing $5 \%$ sheep blood. Bacteria were plated onto PYSS agar plates using isolation streaks and incubated overnight. Individual colonies were transferred from 
PYSS agar plates onto dual layer plates using sterile toothpicks and incubated overnight. Both the colony diameter and the haemolysis diameter were measured.

Challenge of Penaeus monodon larvae. Bath challenge of $P$. monodon nauplii was performed by a modified method used by Muir (1990) and Harris \& Owens (1999). Nauplii were challenged with $10^{6} \mathrm{CFU} \mathrm{ml}^{-1}$ of bacteria per flask of 15 larvae in $150 \mathrm{ml}$. An equivalent volume of PYSS broth was used as a broth control. The 4 naïve strains of Vibrio harveyi without the bacteriophage were also used as controls. The larvae were assessed for survival after $48 \mathrm{~h}$ from initial challenge.

Identification, and isolation of toxic sub-unit bands from Vibrio harveyi Strain 642. The toxic protein subunits from $V$. harveyi Strain 642 were identified in the SDS-PAGE gels by 2 methods. Firstly, the molecular weight of each sub-unit was known to be $58,48,47,46$, 45, 39 and $21 \mathrm{kDa}$ respectively (Harris \& Owens 1999). Secondly, a direct comparison with images of the entire protein profile, including toxin sub-units, reported by Harris \& Owens (1999) ensured that the correct protein bands were isolated.

The antigen for the production of polyclonal and monoclonal antibodies was obtained by running concentrated CFS from Vibrio harveyi Strain 642 on a reducing gel by SDS-PAGE. After the running dye had run off the bottom of the gel, $3 \mathrm{~cm}$ of the side of the gel, including the marker lane, was removed and placed into Coomassie blue stain. The stained gel segment was then re-aligned with the original gel and the area on the unstained gel that correlated with the toxic protein bands was removed with a gel cutter and stored at $4^{\circ} \mathrm{C}$ for emulsion.

Western blots. The transfer of the CFS electrophoresed from gels to polyvinylidene fluoride (PVDF) membrane (Immobilon-P, Millipore), and the subsequent Western blot procedure were performed following the method of Towbin et al. (1979). The monoclonal antibodies (MAbs) (see later subsection) were added undiluted for $1 \mathrm{~h}$. At the end of this period, the blots were washed with PBS, and goat anti-mouse IgY $(\mathrm{H}+$ L)-horseradish peroxidase (HRP) conjugate (Jackson Immuno Research) was added at 1:1000 in diluent (TropBio) for $1 \mathrm{~h}$ and then developed.

Immunisation of mice. Six wk old balb/c male mice were injected 3 times intraperitoneally (i.p.) with specific toxin sub-units from Vibrio harveyi Strain 642, emulsified with PBS, at 2 wk intervals at a dose of $300 \mu \mathrm{l}$. At the last boost, the mice were also boosted with $50 \mu \mathrm{l} \mathrm{CFS} \mathrm{from} V$. harveyi Strain 642 into the tail vein; $4 \mathrm{~d}$ after the final boost, the mice were killed using $\mathrm{CO}_{2}$ and the spleens were removed aseptically.

Hybridoma and MAb production. Hybridomas were produced following the method of Zola (1995).
The spleen cells of the immunised mouse were fused with Sp2/0 myeloma cell line; $14 \mathrm{~d}$ after fusion, hybidomas were screened using an antibody-capture ELISA, and positive wells were expanded and recloned until a stable positive cell line was obtained.

Screening hybridoma supernatants by ELISA. Hybridoma supernatants were screened using an antibody-capture ELISA to determine positive/negative cell lines after fusion; 96-well plates (IWAKI, Crown Scientific) were first coated with $1 \times$ CFS from $\mathrm{Vi}$ brio harveyi Strain 642 in carbonate-bicarbonate buffer, pH 9.6, in a $100 \mu \mathrm{l} \mathrm{well}{ }^{-1}$ for $24 \mathrm{~h}$ at $36^{\circ} \mathrm{C}$. After the plate had been coated with antigen and dried overnight, $100 \mu \mathrm{l}$ of the supernatant from the hybridomas under investigation was added to the wells and further incubated for $1 \mathrm{~h}$. Goat anti-mouse IgG $(\mathrm{H}+\mathrm{L})$ HRP conjugate was added at 1:1000 in diluent at $100 \mu \mathrm{l}$ well ${ }^{-1}$ for $1 \mathrm{~h}$ and 2,2'-azino-di-3-ethylbenzthiazoline6-sulphonic acid (ABTS) (KPL Europe) was added and incubated for a further $1 \mathrm{~h}$ prior to determining the colour formation. Between each step, the wells were washed 3 times with ELISA wash buffer (TropBio). Results were read with an ELISA reader (Labsystems, Multiscan EX) using dual absorbance of 414 and $492 \mathrm{~nm}$.

Statistical analysis. All data were checked for normality and, if required, transformed to meet assumptions of normality. Analysis between groups was performed by a univariate analysis of variance, and a comparison of individual means was performed using a LSD multiple comparison.

\section{RESULTS}

\section{SDS-PAGE analysis of CFS derived from strains of Vibrio harveyi uninfected and infected with Bacteriophage VHML}

There was a visible difference in protein production from the strains of Vibrio harveyi with the bacteriophage compared to the same strains without the bacteriophage. It was also observed that the Virulent Strain 642 produced much higher levels of extra-cellular protein compared to the previously naïve strains that were infected with Bacteriophage VHML.

From these SDS-PAGE gels it was visually evident that Bacteriophage VHML caused an up-regulation of certain extracellular proteins from Vibrio harveyi Strains 12, 20, 45 and 645 (Figs. 1, 2, 3 \& 4 respectively). The 4 Strains 12, 20, 45 and 645 also exhibited some additional protein bands from the infected strains compared with the same strain without the bacteriophage. 


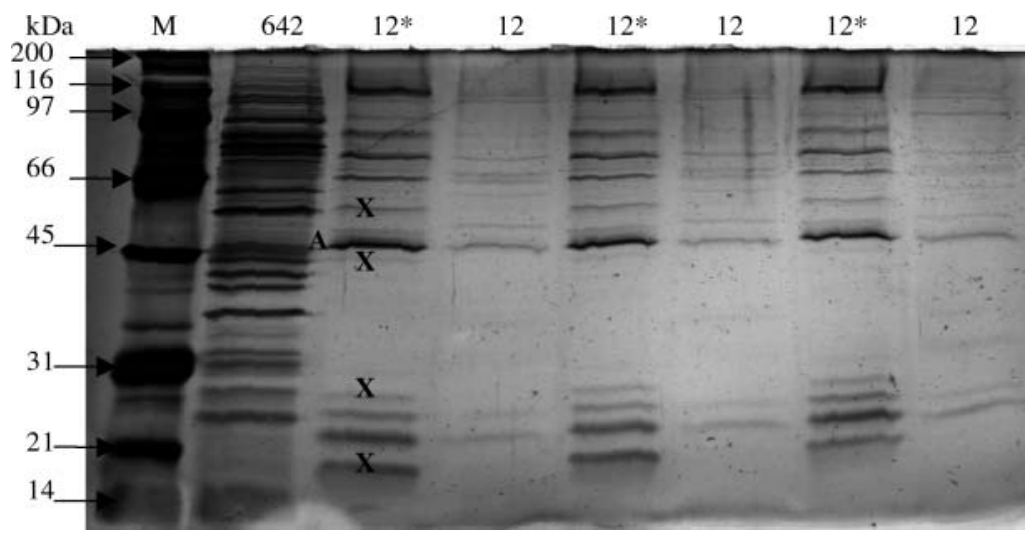

Fig. 1. Vibrio harveyi Strain 12. Protein profile generated by SDS-PAGE $(12 \%$, silver stained) showing cell-free supernatant extract. M: marker; *: Bacteriophage-infected strain; X: extra protein band; A: up-regulation of possible toxin band

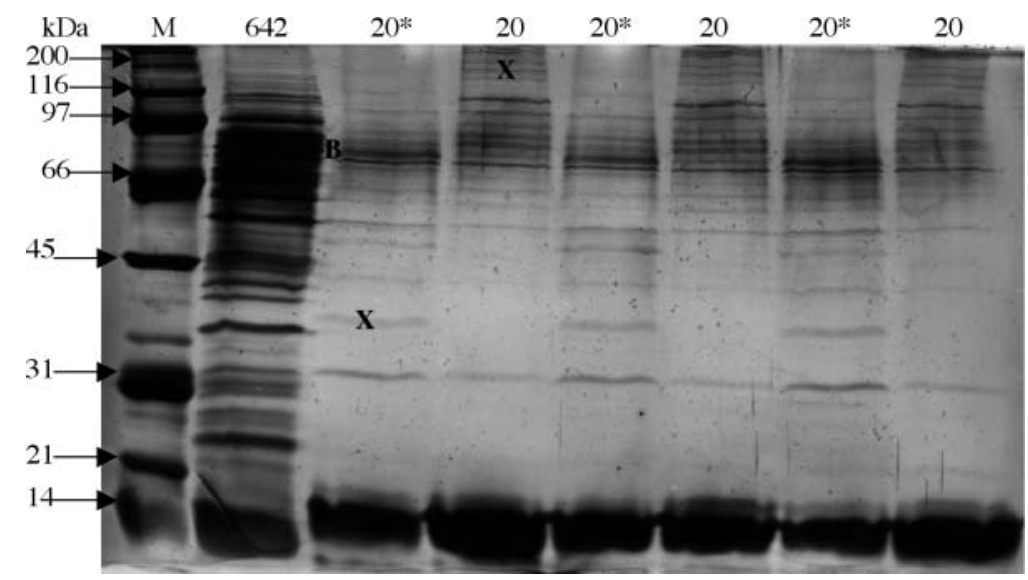

Fig. 2. Vibrio harveyi Strain 20. Protein profile generated by SDS-PAGE $(12 \%$, silver stained) showing cell-free supernatant extract. Notation as in Fig. 1

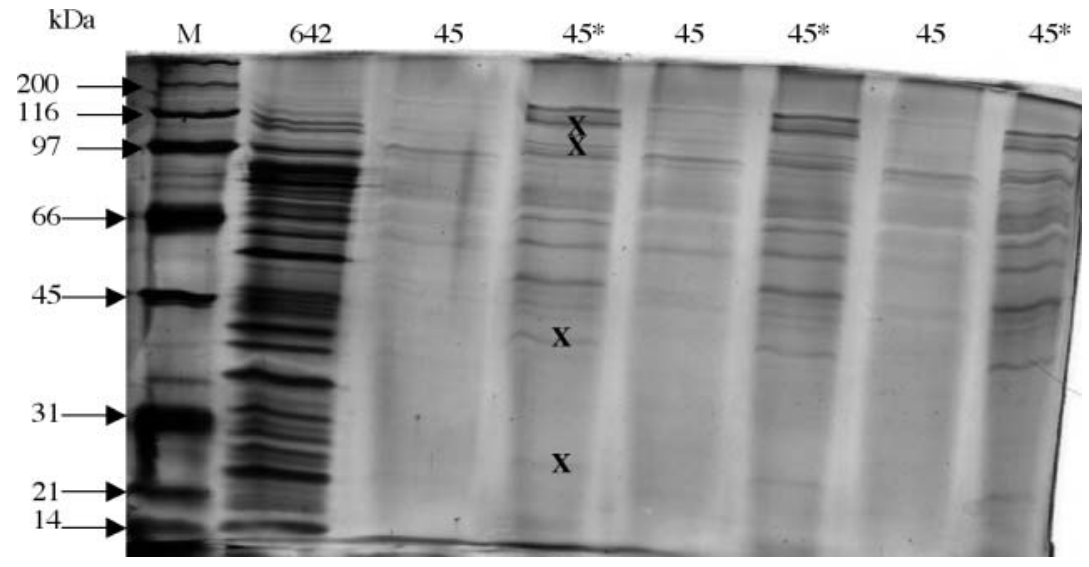

Fig. 3. Vibrio harveyi Strain 45. Protein profile generated by SDS-PAGE $(12 \%$, silver stained) showing cell-free supernatant extract. Notation as in Fig. 1

\section{Haemolysin production on dual layer agar}

The differences in haemolysin production from Vibrio harveyi Strains 642, 12, 20, 45 and 645 are shown in Fig. 5.

The halo size and colony size from the particular strains of Vibrio harveyi that were infected with Bacteriophage VHML were, as a group, significantly different $(F=74.9$, df $=8,333, \mathrm{p}<0.001$ and $F=$ 51.1, df $=8,331, \mathrm{p}<0.001$ respectively) from the strains without Bacteriophage VHML (Tables 1 \& 2). The size of the haemolysin halo of the individual strains of $V$. harveyi that were infected with the bacteriophage showed a significant difference ( $p<0.001$ ) from the same individual strains without the bacteriophage, except for Strain 20, which was not significantly different $(p>0.05)$.

The diameter of the haemolysin halo of Strain 45 with the bacteriophage was significantly different $(p<0.001)$ from that of all other strains of bacteria tested. The diameter of the haemolysin halo of Strain 45 without the bacteriophage was significantly different $(p<0.05)$ from that of all other strains, except for Strains 12 and 20 with the bacteriophage. The diameter of the haemolysin halo of Strain 12 without the bacteriophage was significantly different $(p<0.001)$ from that of all other strains, except for Strain 645 without the bacteriophage.

The colony sizes of the Vibrio harveyi Strains 20 and 645 infected with the bacteriophage were significantly different $(\mathrm{p}<$ 0.001) from the sizes of the same strains without the bacteriophage. However, Strains 12 and 45 infected with the bacteriophage were not significantly different ( $p>0.05$ ) from the same strains without the bacteriophage (Table 2).

\section{Bath challenge of Penaeus monodon larvae with Bacterial Strains 12, 20, 45 and 645 with and without phages}

From Fig. 6, it can be seen that mortalities caused by the Vibrio harveyi strains with the bacteriophage were significantly greater $(F=34.9$, df $=9,129, \mathrm{p}<0.001)$ than mortalities caused by the strains of $V$. harveyi without the bacteriophage. 


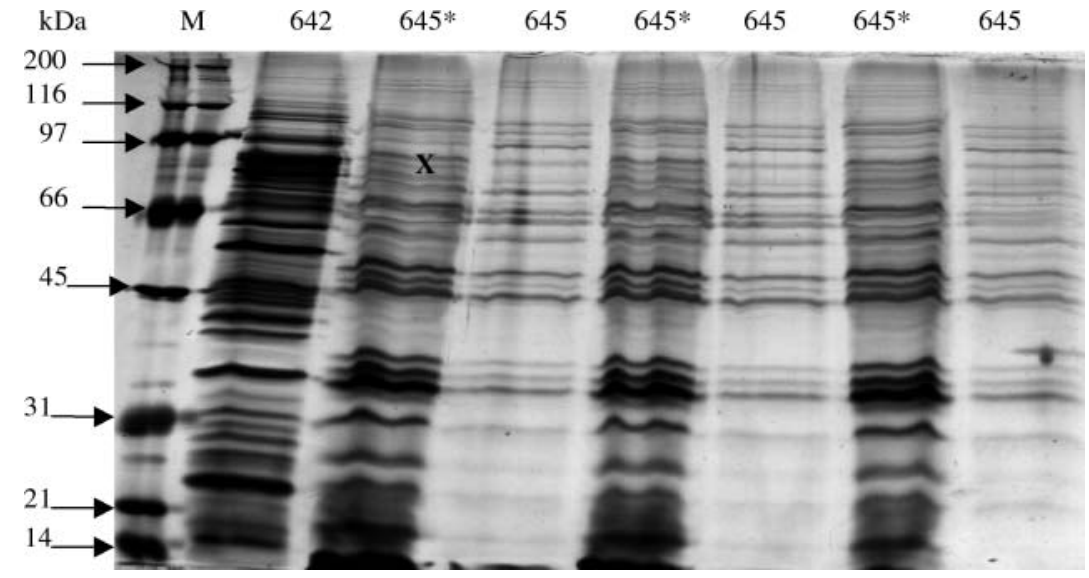

Fig. 4. Vibrio harveyi Strain 645. Protein profile generated by SDS-PAGE (12\%, silver stained) showing cell-free supernatant extract. Notation as in Fig. 1

Table 3 shows that $V$. harveyi Strain 642 caused significantly higher $(\mathrm{p}<0.001)$ mortalities among the larval prawns than any of the other bacterial strains.

A statistical analysis using Pearson's correlation showed that there were significant correlations $(\mathrm{p}<$ 0.05 ) between an increase in the size of the haemolysin halo and an increase in colony size of the bacteria with increased mortalities. However, these data are limited due to there being only 9 points of data.

\section{Monoclonal antibody exotoxin subunits of Vibrio harveyi Strain 642}

The results of the 4 strongest MAbs against specific protein bands in Vibrio harveyi Strain 642 and the 4 previously naïve strains are shown in Table 4 .

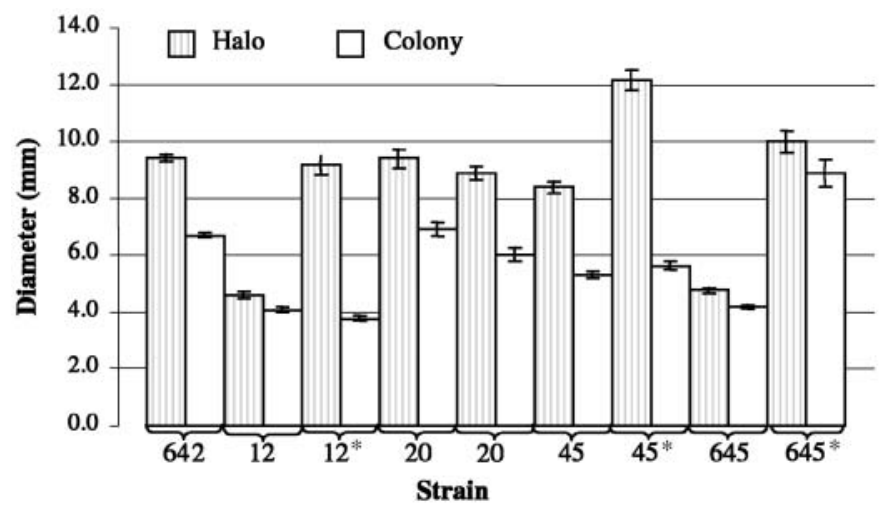

Fig. 5. Vibrio harveyi. Mean colony diameter and haemolysin halo diameter of the previously naïve Strains 12, 20, 45 and 645 with and without the bacteriophage. *: Bacteriophage infected strain
The 4 MAbs detected more than 1 specific band in Vibrio harveyi Strain 642 (Table 4). MAbs from Monoclone 3.3H detected 1 band in Strain 12 infected with the bacteriophage and MAbs from monoclone 4.5B detected 1 band in each of Strains 12, 20 and 645. The MAbs from Monoclones 4.9F and 8.10F detected no other protein bands other than in Strain 642, and protein bands in Strain 45 were not detected by any of the monoclonal antibodies.

\section{DISCUSSION}

Some strains of Vibrio harveyi have been shown to be capable of devastating commercial penaeid hatcheries, while other strains have been shown to be a part of the natural flora of the marine environment and cause no disease. Until now, this strain-specific virulence of $V$. harveyi has not been understood. Pizzutto \& Hirst (1995) suggested that virulence may be explained by a genetic transfer of virulence factors. Bacteriophage-mediated virulence has been suggested by Ruangpan et al. (1999). However, no work was undertaken to prove this. Bacteriophagemediated virulence has previously been reported for a variety of bacteria. For example, under the influence of specific bacteriophages, Corynebacterium diphtheriae will produce diphtherial toxin (Rajadhyaksha \& Rao 1965), Group A streptococci produce pyrogenic exotoxin (Johnson et al. 1980), staphylococci produce enterotoxin A and staphylokinase (Coleman et al. 1989), Pseudomonas aeruginosa produces cytotoxins (Hayashi et al. 1990), some strains of Escherichia coli produce both verotoxins and cytotoxins (Takeda \& Murphy 1979, Newland et al. 1985, Karch et al. 1987) and V. cholerae

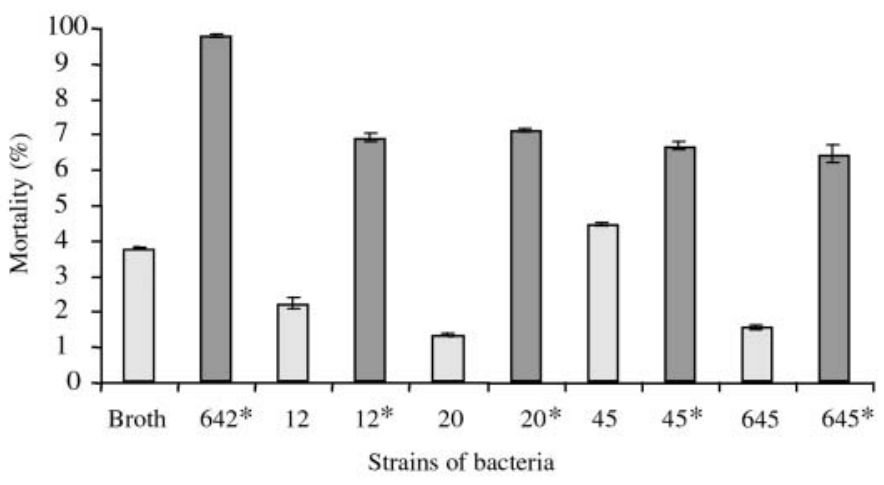

Fig. 6. Penaeus monodon. Mean mortalities and standard error for 3 replicate flasks of 15 nauplii larvae $48 \mathrm{~h}$ after being bathchallenged with strains of Vibrio harveyi. *: Bacteria with bacteriophage 
Table 1. Vibrio harveyi. Differences (p values) in haemolysin halo diameter of individual strains compared with other strains. *Bacteriophage-infected strain. Bold print highlights comparisons between the same strain with and without bacteriophage

\begin{tabular}{|lcccccccc|}
\hline & 12 & $12^{*}$ & 20 & $20^{*}$ & 45 & $45^{*}$ & $642^{*}$ & 645 \\
\hline $12^{*}$ & $\mathbf{0 . 0 0 1}$ & & & & & & & \\
20 & 0.001 & 0.599 & & & & & & \\
$20^{*}$ & 0.001 & 0.547 & $\mathbf{0 . 2 8 6}$ & & & & & \\
45 & 0.001 & 0.079 & 0.03 & 0.289 & & & & \\
$45^{*}$ & 0.001 & 0.001 & 0.001 & 0.001 & $\mathbf{0 . 0 0 1}$ & & & \\
$642^{*}$ & 0.001 & 0.524 & 0.958 & 0.223 & 0.014 & 0.001 & & \\
645 & 0.727 & 0.001 & 0.001 & 0.001 & 0.001 & 0.001 & 0.001 & \\
$645^{*}$ & 0.001 & 0.029 & 0.150 & 0.007 & 0.001 & 0.001 & 0.117 & $\mathbf{0 . 0 0 1}$ \\
& & & & & & & & \\
\hline
\end{tabular}

Table 2. Vibrio harveyi. Differences (p values) in colony diameter of individual strains compared with other strains. ${ }^{*}$ Bacteriophage-infected strain. Bold print highlights comparisons between the same strain with and without bacteriophage

\begin{tabular}{|lcccccccc|}
\hline & 12 & $12^{*}$ & 20 & $20^{*}$ & 45 & $45^{*}$ & $642^{*}$ & 645 \\
\hline $12^{*}$ & $\mathbf{0 . 4 8 0}$ & & & & & & & \\
20 & 1.000 & 0.480 & & & & & & \\
$20^{*}$ & 0.001 & 0.001 & $\mathbf{0 . 0 0 1}$ & & & & & \\
45 & 0.005 & 0.001 & 0.005 & 0.082 & & & & \\
$45^{*}$ & 0.001 & 0.001 & 0.001 & 0.351 & $\mathbf{0 . 4}$ & & & \\
$642^{*}$ & 0.001 & 0.001 & 0.001 & 0.091 & 0.001 & 0.005 & & \\
645 & 0.835 & 0.268 & 0.835 & 0.001 & 0.001 & 0.001 & 0.001 & \\
$645^{*}$ & 0.001 & 0.001 & 0.001 & 0.001 & 0.001 & 0.001 & 0.001 & $\mathbf{0 . 0 0 1}$ \\
\hline
\end{tabular}

Table 3. Penaeus monodon. Differences (p values) in mortalities of larval prawns caused by individual strains compared to other strains. ${ }^{*}$ Bacteriophage-infected strain. Bold print highlights comparisons between the same strain with and without bacteriophage

\begin{tabular}{|c|c|c|c|c|c|c|c|c|c|}
\hline & No bacteria & a 12 & $12^{*}$ & 20 & $20^{*}$ & 45 & $45^{*}$ & $642^{*}$ & 645 \\
\hline 12 & 0.780 & & & & & & & & \\
\hline $12^{*}$ & 0.001 & 0.001 & & & & & & & \\
\hline 20 & 0.194 & 0.307 & 0.001 & & & & & & \\
\hline $20^{*}$ & 0.001 & 0.001 & 0.709 & 0.001 & & & & & \\
\hline 45 & 0.926 & 0.852 & 0.001 & 0.228 & 0.001 & & & & \\
\hline $45^{*}$ & 0.001 & 0.001 & 0.194 & 0.001 & 0.353 & 0.001 & & & \\
\hline $642^{*}$ & 0.001 & 0.001 & 0.001 & 0.001 & 0.001 & 0.001 & 0.001 & & \\
\hline 645 & 0.265 & 0.403 & 0.001 & 0.852 & 0.001 & 0.307 & 0.001 & 0.001 & \\
\hline $645^{*}$ & 0.002 & 0.001 & 0.641 & 0.001 & 0.040 & 0.002 & 0.079 & 0.001 & 0.001 \\
\hline
\end{tabular}

Table 4. Vibrio harveyi Strains 12, 20, 45 and 645. Number of protein bands to be detected with MAbs 3.3H, 4.5B, 4.9F, 8.10F to Strain 642 toxin bands. ${ }^{*}$ Bacteriophage-infected strain. (Note: $V$. harveyi Strain 642 does not exist with its bacteriophage)

\begin{tabular}{|lrrrrrc|}
\hline Monoclone line & $642^{*}$ & $12^{*}$ & $20^{*}$ & $45^{*}$ & $645^{*}$ & $12,20,45,645$ \\
\hline $3.3 \mathrm{H}$ & 7 & 1 & 0 & 0 & 0 & 0 \\
$4.5 \mathrm{~B}$ & 10 & 1 & 1 & 0 & 1 & 0 \\
$4.9 \mathrm{~F}$ & 8 & 0 & 0 & 0 & 0 & 0 \\
$8.10 \mathrm{~F}$ & 4 & 0 & 0 & 0 & 0 & 0 \\
\hline
\end{tabular}

Strains 01 and 0139 will produce cholera toxin (Waldor \& Mekalanos 1996). Our study is the first report showing clear evidence that a bacteriophage can confer virulence to strains of V. harveyi.

In this investigation, 5 separate experiments were undertaken to investigate and confirm that the presence of Bacteriophage VHML is either partly or fully responsble for the virulence in Vibrio harveyi Strain 642. Optical density values were used as a suggestive measure that Bacteriophage VHML infected the previously naïve $V$. harveyi Strains 12, 20, 45 and 645. Haemolysin production on dual layer blood/PYSS agar ( $3 \% \mathrm{NaCl})$, protein profiles and the production of MAbs against the toxic protein bands of Strain 642 were used as confirmational methods that the bacteriophage had infected the 4 previously naïve strains. These 3 experiments also suggested that the bacteriophage confers virulence. The bioassay experiment was used to show that the previously naïve strains of $V$. harveyi infected with the bacteriophage were significantly more pathogenic to larval penaeid prawns than the same strains uninfected with the bacteriophage. This experiment confirmed the transduction of virulence via the bacteriophage into strains of bacteria. The toxic protein bands in $V$. harveyi Strain 45 were not seen with the MAbs. This may have been due to either the production of these protein bands being to small to be visualised or the epitope being modified in some way. This needs further work to be clarified.

The level of haemolysin production has been used often as an indicator of potential virulence. Chang et al. (2000) suggested that the pathogenicity of bacteria isolated from prawn hepatopancrei was correlated with lysis of prawn haemocytes. Of 38 pathogenic and 170 non-pathogenic strains of Klebsiella sp., 76 and $0.59 \%$ of the strains, respectively, were haemolytic (Singh \& Sharma 1999). These reports support the findings that the up-regulated haemolysin production from the 4 
Vibrio harveyi strains infected with the bacteriophage compared with the same strains uninfected with the bacteriophage correlated with an increase in virulence.

Harris \& Owens (1999) used SDS-PAGE to show that Vibrio harveyi Strain 642 secreted a protein that was toxic to larval penaeid prawns. This protein had 6 subunits with molecular sizes of approximately $58,48,47$, 46,45 and $39 \mathrm{kDa}$. The 4 strains of $V$. harveyi used in the present study showed considerable differences in protein production between the strains infected and uninfected with the bacteriophage using SDS-PAGE. This was demonstrated by differences in the level of protein synthesis, and some strains demonstrated additional proteins that were similar in size to the toxin bands from Strain 642. This experiment demonstrated that Bacteriophage VHML caused up-regulation of protein excretion in 4 of the strains infected with the bacteriophage.

The use of MAbs is a popular and specific practice for the detection of exotoxins. MAbs have recently been developed for the detection of aflaxtoxin $\mathrm{B}_{1}$, which is the most toxic member of a group of toxic compounds produced in strains of Aspergillus flavus (Gathumbi et al. 2001). Wagner et al. (1999) produced antibodies against a major exotoxin of the fish pathogen Aeromonas salmonicida ssp. achromogenes. The MAbs developed for the detection of the toxin subunits from Strain 642 were used to detect the same protein bands in Vibrio harveyi Strains 12, 20, 45 and 645. The MAbs showed that 3 out of the 4 strains infected with the bacteriophage produced bands that were recognised by the MAbs while no bands were detected in the strains uninfected with the bacteriophage. The MAbs confirmed that the infection of Bacteriophage VHML resulted in proteins being synthesised and excreted by the previously naive bacteria and that some of these proteins were recognised as sub-units of the exotoxin from $V$. harveyi Strain 642.

Bioassays can be used to determine the virulence of an organism towards the experimental animal. Muir (1990) used bath inocula to determine the pathogenicity of various bacteria towards prawn larvae. Similarly, Harris \& Owens (1999) determined the virulence of Vibrio harveyi Strain 642 by using a bath challenge with larval prawns. The bioassay in this study demonstrated that the $4 V$. harveyi Strains 12, 20, 45 and 645 infected with Bacteriophage VHML caused higher mortality in larval penaeid prawns than the same strains uninfected with the same bacteriophage. This demonstrates that Bacteriophage VHML confers virulence to previously naïve strains of $V$. harveyi.

The larval prawns immersed in broth with no bacteria in the bioassay showed relatively higher mortalities compared with those for Strains 12, 20 and 645 uninfected with the bacteriophage. This may have been due to the fact that prawn nauplii begin to feed at approximately $40 \mathrm{~h}$ after hatching. The nauplii were challenged with the bacteria $4 \mathrm{~h}$ after hatching and the bioassay ran for $48 \mathrm{~h}$. Since protozoea are filter-feeders, the protozoea that were challenged with the bacteria uninfected with the bacteriophage would have been feeding on those bacteria $40 \mathrm{~h}$ post-hatching after they moulted into protozoea, while those immersed in the broth would have had no bacteria to feed on and possibly died of starvation.

In conclusion, the infection of Bacteriophage VHML in Vibrio harveyi Strains 12, 20, 45 and 645 resulted in up-regulation of haemolysin, an up-regulation of protein synthesis with some proteins being recognised as the same toxic subunits found in V. harveyi Strain 642, and an increase in virulence towards larval penaeid prawns. It is concluded that Bacteriophage VHML could confer virulence to $V$. harveyi Strains 12, 20, 45 and 645 and that Bacteriophage VHML either fully or partly confers virulence in $V$. harveyi Strain 642 . The abundance of VHML in the environment is unknown. Other strains of bacteria are currently being investigated to determine if VHML can confer virulence to them.

\section{LITERATURE CITED}

Baticados MCL, Lavilla-Pitogo CR, Cruz-Lacierda ER, de la Pena LD, Sunaz NA (1990) Studies on the chemical control of luminous bacteria Vibrio harveyi and V. splendidus isolated from diseased Penaeus monodon larvae and rearing water. Dis Aquat Org 9:133-139

Chang C, Liu W, Shyu C (2000) Use of prawn blood agar hemolysis to screen for bacteria pathogenic to cultured tiger prawns Penaeus monodon. Dis Aquat Org 43: 153-157

Coleman DC, Sullian DJ, Russel RJ, Arbuthnott JP, Carey BF, Pomeroy HM (1989) Staphylococcus aureus bacteriophage mediating the simultaneous lyogenic conversion of beta-lysin, staphylokinase and enterotoxin A: molecular mechanism of triple conversion. J Gen Microbiol 135: 1679-1697

Gathumbi JK, Usleber E, Martlbauer E (2001) Production of ultrasensitive antibodies against aflatoxin $\mathrm{B}_{1}$. Lett Appl Microbiol 32:349-351

Harris LJ (1998) An investigation into the virulence and the control of strains of Vibrio harveyi pathogenic to larvae of the black tiger prawn, Penaeus monodon. Doctoral thesis, James Cook University, Townsville

Harris LJ, Owens L (1999) Production of exotoxins by two luminous Vibrio harveyi strains known to be primary pathogens of Penaeus monodon larvae. Dis Aquat Org 38: $11-22$

Hayashi T, Baba T, Matsumoto H, Terawaki T (1990) Phageconversion of cytotoxin production in Pseudomonas aeruginosa. Molec Microbiol 4:1703-1709

Jiravanichpaisal P, Miyazaki T, Limsuwan C (1994) Histopathology, biochemistry, and pathogenicity of Vibrio harveyi infecting black tiger prawn Penaeus monodon. $\mathrm{J}$ Aquat Anim Health 6:27-35 
Johnson LP, Schlievert PM, Watson DW (1980) Transfer of group A streptococcal pyrogenic exotoxin production to nontoxigenic strains of lysogenic conversion. Infect Immun 28:254-257

Karch H, Heeseman J, Laufs R (1987) Phage-associated cytotoxin production by and enteroadhesiveness of enteropathogenic Escherichia coli isolated from infants with diarrhea in West Germany. J Infect Dis 155:707-715

Karunasagar I, Pai R, Malathi GR, Karunasagar I (1994) Mass mortality of Penaeus monodon larvae due to antibiotic resistant Vibrio harveyi infection. Aquaculture 128: 203-209

Laemmli UK (1970) Cleavage of structural proteins during the assembly of the head of bacteriophage T4. Nature 227: 680-685

Lavilla-Pitogo CR, Cecilic M, Baticados L, Cruz-Lacierda ER, de la Pena LD (1990) Occurrence of luminous bacterial disease of Penaeus monodon larvae in the Philippines. Aquaculture 91:1-13

Liu PC, Lee KK, Yii KC, Kou GH, Chen SN (1996) Isolation of Vibrio harveyi from diseased kuruma prawns Penaeus japonicus. Curr Microbiol 33:129-132

Maniotus T, Fritsch EF, Sambrook J (1982) Molecular cloning; a laboratory manual. Cold Spring Harbour Laboratory Press, Plainview

Muir P (1990) Factors affecting the survival of penaeid prawns in culture with particular reference to the larval stages. $\mathrm{PhD}$ thesis, Department of Microbiology and Immunology, James Cook University, Townsville

Newland JW, Strockbine NA, Miller SF, O'Brian AD, Holmes RK (1985) Cloning of shiga-like toxin structural genes from a toxin converting phage of Escherichia coli. Science 230:179-181

Oakey HJ, Owens L (2000) A new bacteriophage, VHML, isolated from a toxin-producing strain of Vibrio harveyi in tropical Australia. J Appl Microbiol 89:702-709

Pizzutto M (1992) The evolutionary postion of virulent isolates of Vibrio harveyi as determined by protein analysis and

Editorial responsibility: Timothy Flegel,

Bangkok, Thailand
DNA fingerprinting. BSc (Hon) thesis, Department of Microbiology and Immunology, James Cook University, Townsville

Pizzutto M, Hirst RG (1995) Classification of isolates of Vibrio harveyi virulent to Penaeus monodon larvae by protein profile analysis and M13 DNA fingerprinting. Dis Aquat Org 21:61-68

Rajadhyaksha AB, Rao SS (1965) The role of phage in the transduction of the toxinogenic factor in Corynebacterium diphtheriae. J Gen Microbiol 40:421-429

Ruangpan L, Danayadol Y, Direkbusarakom S, Siurauratana S, Flegel TW (1999) Lethal toxicity of Vibrio harveyi to cultivated Penaeus monodon induced by a bacteriophage. Dis Aquat Org 35:195-201

Singh BR, Sharma VD (1999) Haemolytic pattern of pathogenic and non-pathogenic Klebsiella isolated from foods and clinical case. Indian J Anim Sci 69:762-765

Sunaryanto A, Mariam A (1986) Occurrence of a pathogenic bacteria causing luminescence in penaeid larvae in Indonesian hatcheries. Bull Brackishwater Aquacult Dev Cent 8:105-112

Takeda Y, Murphy JR (1979) Bacteriophage conversion of heat-liable enterotoxin of Escherichia coli. J Bacteriol 133: 172-177

Towbin HT, Staehelin T, Gordon J (1979) Electrophoretic transfer of proteins from polyacrylamide gels to nitrocellulose sheets: procedure and some applications. Proc Natl Acad Sci USA 76:4350-4354

Wagner U, Gudmundsdottir BK, Drossler K (1999) Monoclonal antibodies against AsaP1, a major exotoxin of the fish pathogen Aeromonas salmonicida ssp. achromogenes, and their application in ELISA. J Appl Microbiol 87:620-629

Waldor MK, Mekalanos JJ (1996) Lysogenic conversion by a filamentous phage encoding cholera toxin. Science 272: 1910-1914

Zola H (1995) Monoclonal antibodies; the second generation. BIOS Scientific Publishers, Oxford

Submitted: April 10, 2002; Accepted: August 13, 2002

Proofs received from author(s): March 20, 2003 